\title{
A Mediterranean element of the vegetation: Junco maritimi-Cladietum marisci - a new association for Ukraine
}

\author{
Anastasia Davydova' ${ }^{1}$
}

Key words: Cladium mariscus communities, associations, marshland, swamp, Europe, Junco maritimi-Cladietum marisci.

Ključne besede: združbe z vrsto Cladium mariscus, asociacije, mokrišče, močvirje, Evropa, Junco maritimi-Cladietum marisci.
Received: 26. 3. 2019

Revision received: 21. 1. 2020

Accepted: 18. 5. 2020

\begin{abstract}
Cladium mariscus (L.) Pohl (Cyperaceae) is a rare species in Europe considered by several authors to be a relict of the early Holocene period. It is listed in the Red Data Book of Ukraine, Annexes of the Habitat Directive and the Bern Convention. Communities with domination of this species are included in the Green Data Book of Ukraine. Substantial differences in major ecological factors for Cladium mariscus communities in the western (carbonate bogs) and the southern (marshes and floating swamps of the northern Black Sea) regions of Ukraine were shown. The author carried out comparisons of relevés characterizing different communities with Cladium mariscus within Europe. Based on the results of TWINSPAN analysis, four associations were identified, confirmed by floristic indices and ecological data: Cladietum marisci Allorge 1921, Soncho maritimiCladietum marisci (Br.-Bl. \& O. de Bolòs 1957) Cirujano 1980, Dorycnio rectiCladietum marisci Gradstein \& Smittenberg 1977 and Junco maritimi-Cladietum marisci (Br.-Bl. \& O. de Bolòs 1957) Géhu \& Biondi 1988. Thus, in addition to the association Cladietum marisci, a new one was indicated for Ukraine, Junco maritimi-Cladietum marisci.
\end{abstract}

Izvleček

Cladium mariscus (L.) Pohl (Cyperaceae) je v Evropi redka vrsta in številni avtorji jo uvrščajo med relikte iz zgodnjega holocena. Uvrščena je na rdeči seznam Ukrajine, Habitatno direktivo in Bernsko konvencijo. Združbe, v katerih je vrsta dominantna, so uvrščene na zeleni seznam Ukrajine. Med združbami z vrsto Cladium mariscus v Ukrajini obstajajo znatne razlike v rastiščnih dejavnikih med zahodnimi (karbonatna barja) in južnimi (mokrišča in plavajoča močvirja ob severnih obalah Črnega morja) regijami. Avtorica je naredila primerjavo vegetacijskih popisov različnih združb s to vrsto v Evropi. Na osnovi rezultatov TWINSPAN analize je ugotovila štiri asociacije, ki jih je potrdila s florističnimi indeksi in ekološkimi podatki: Cladietum marisci Allorge 1921, Soncho maritimiCladietum marisci (Br.-Bl. \& O. de Bolòs 1957) Cirujano 1980, Dorycnio rectiCladietum marisci Gradstein \& Smittenberg 1977 in Junco maritimi-Cladietum marisci (Br.-Bl. \& O. de Bolòs 1957) Géhu \& Biondi 1988. Ugotovila je tudi, da v Ukrajini poleg asociacije Cladietum marisci obstaja tudi asociacija Junco maritimi-Cladietum marisci. 


\section{Introduction}

The genus Cladium P. Browne comprises 3 species which are typical for temperate, subtropical and partly tropical regions (Plants of world..., 2020). One of them is C. mariscus (L.) Pohl, distributed in Eurasia and accepted in the wide sense to consist of an uncertain number of infraspecific taxa. In Ukraine, two species from this genus (C. mariscus (L.) Pohl and C. martii (Roem. et Schult.) K. Richt.) are indicated by I. M. Danylyk (Danylyk 2011, 2012). The key for their determination proposed by Danylyk was compiled from T. V. Egorova's paper (1976), who accepted these taxa at subspecies level as $C$. mariscus subsp. mariscus and C. mariscus (L.) Pohl subsp. martii (Roem \& Schult.) T.V. Egorova.

The latter subspecies has actually been described from Spain as Isolepis martii Roem. et Schult. (Egorova 1976). Tzvelev (1966) advanced the idea of a divided area of the genus Cladium in view of the evolutionarily younger $C$. mariscus represented in Europe. The areas of distribution of two older close species, C. grossheimii Pobed. and $C$. medwedewii (Meinsh.) Grossh., are situated along the Black Sea (Ukraine, Abkhazia) and near the Caspian Sea (Azerbaijan, Iran), respectively. Both these species are confined to coastal areas (Tzvelev 1966), but now they are mainly synonymized with $C$. mariscus subsp. martii which some other authors have considered to be a synonym of $C$. mariscus subsp. mariscus (Castroviejo et al. 2007, Verloove 2012).

According to the Red Data Book of Ukraine, C. mariscus is protected on the territory of Shatsk National Nature Park in the Volyn region and C. mariscus ssp. martii - in "Dzharylhatskyi" National Nature Park in the Kherson region (Andrienko et. al. 2009). In the Green Data Book of Ukraine, the communities of "Cladieta marisci" (association Cladietum (marisci) phragmitosum (australis), Cladietum marisci purum, Cladietum (marisci) caricosum (acutiformis), Cladietum (marisci) schoenosum (ferruginei) (Andrienko-Malyuk \& Dubyna 2009) are indicated. Cladium mariscus has had the status of a relict species confirmed by various palaeoecological studies (Pokorný et al. 2010, Gałka \& Tobolski 2012, Hájková et al. 2013).

In addition to the inconsistency of taxonomical status of Cladium mariscus, there are several problems with the syntaxonomy of its communities in Ukraine. This species is diagnostic for the association Cladietum marisci Allorge 1921 (Allorge 1921, Dengler et al. 2004). Currently, two isolated fragments of this species distribution are known from the territory of Ukraine - in western regions on calcareous fens and in southern regions on salt depressions between dune slacks. I therefore decided to compare the existing relevés from different locations in Ukraine with a protologue to discover significant differences based on ecological factors. There have previously been suggestions for classifying variants based on various ecological factors (Buczek 2005, Borsukevych 2008). However, these data concern only western Ukrainian communities on calcareous fens and peatlands.

The main objective was to conduct syntaxonomic analysis of Ukrainian plant communities dominated by Cladium mariscus and compare them with similar ones from other European regions. In addition, the author attempted to study the features of ecological differentiation for these communities and to find differences in their floristic composition.

\section{Material and methods}

\section{The studied area}

The research territory was "Dzharylhatskyi" National Nature Park located in the southern part of Ukraine. This area includes the island of Dzharylhach in the Black Sea and continental areas, which are mainly represented by forest cultures and ruderal plant communities. The island of Dzharylhach is $42 \mathrm{~km}$ long, $4.6 \mathrm{~km}$ at its widest (Ardamatskaya et al. 2000). This island is an elevated sand-shell spit formed at the beginning of the Quaternary period by the accumulation of bottom sediments (Ardamatskaya et al. 2000). Between 700 and 1700 years ago, it was the eastern part of a single spit Dzharylhach-Tendra (Pravotorov 1967). The most represented soil types are sands and salt soils. The main climatic features are a predominance of eastern and north-eastern winds, relatively low humidity of the air, low cloudiness, slight precipitation and relatively large daily and annual amplitudes of air temperature fluctuations. The territory is located in the zone of hot-summer humid continental climate (Peel et. al. 2007). The average annual air temperature is $+10^{\circ} \mathrm{C}$. The lowest temperatures are observed in January (average monthly temperature $-2.6{ }^{\circ} \mathrm{C}$ ) and the highest values are recorded in July $\left(+22.9^{\circ} \mathrm{C}\right)$. Usually $270-345 \mathrm{~mm}$ of precipitation falls annually (Ardamatskaya et al. 2000, Shaposhnikova 2017).

There is only one type of vegetation in the studied area according to the Map of the Natural Vegetation of Europe - western and central Pontic desert steppes (Bohn et al. 2004).

\section{Dataset}

We used 172 relevés made by different authors according to the Braun-Blanquet approach (Braun-Blanquet 1964, Westoff \& van der Maarel 1973) for critical analysis and 


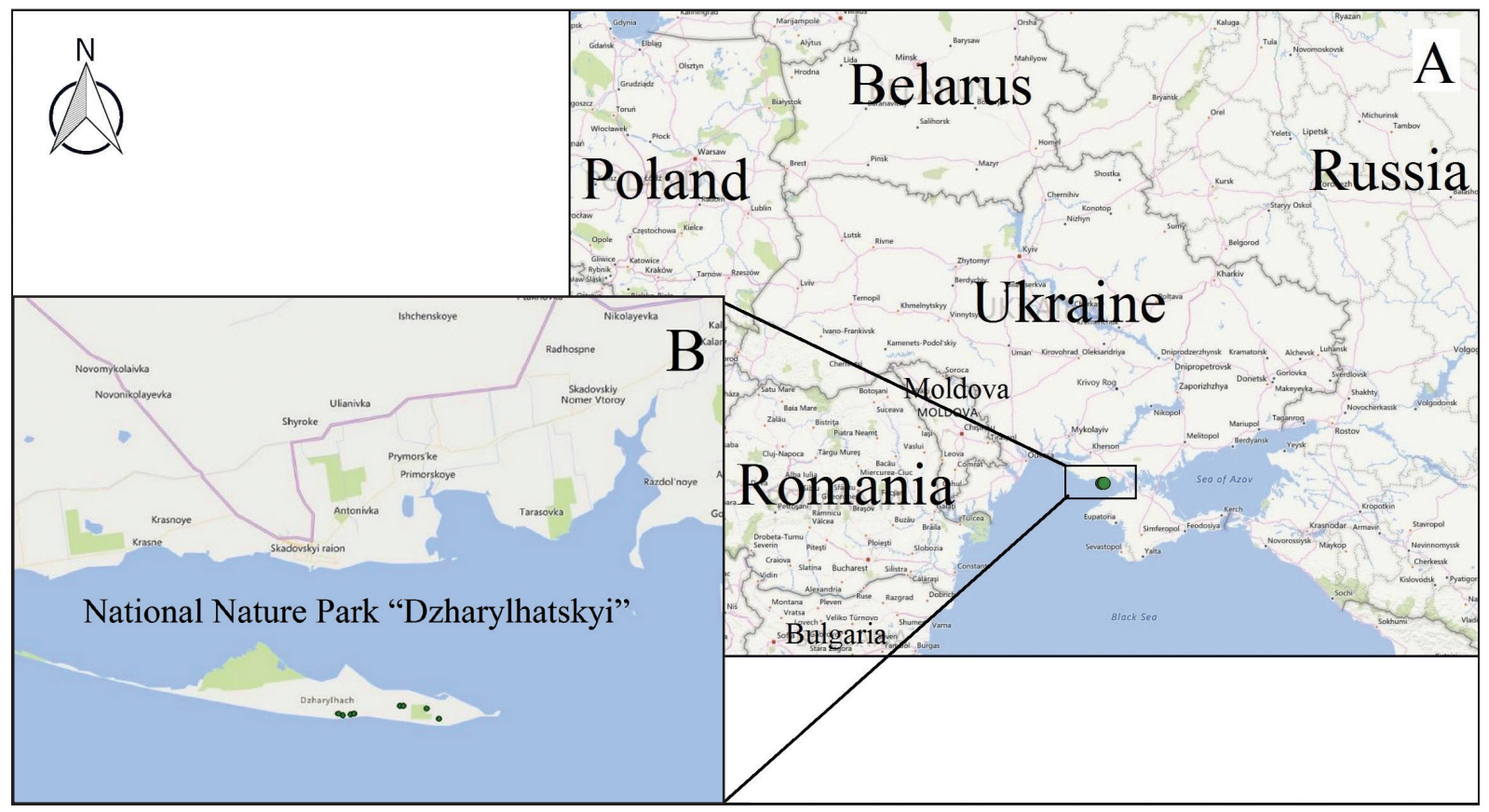

Figure 1: Map of the research area: A - general location in eastern Europe, B - location within the southern part of Ukraine (green points - localities of Cladium mariscus).

Slika 1: Zemljevid raziskovanega območja: A - splošna lokacija v vzhodni Evropi, B - lokacija v južnem delu Ukrajine (zelene točke - lokacije vrste Cladium mariscus).

construction of the classification scheme. Six of them were made by the author on the research territory and five of them are unpublished relevés from Dzharylhach island by D. V. Dubyna. Other relevés were published in various papers and were carried out in other regions: 12 - in the western region of Ukraine (Datsyuk \& Andrienko 2013, Chorna 2013) and 151 - in other countries of Europe: Great Britain (Wheeler 1980: 1 relevé), Greece (Theocharopoulos et al. 2006: 18), Croatia (Stančić et al. 2010: 15), Crete (Gradstein \& Smittenberg, 1977: 14), France (Allorge 1921: 1), Hungary (Lájer 2006: 6), Ireland (Mooney \& O'Connell 1990: 14), Italy (Biondi et al. 2006: 11, Taffetani 2011: 2, Lastrucci et al. 2017: 8, eVeg (Géhu \& Biondi 1988): 5, eVeg (Géhu \& Biondi 1994): 1), Netherlands (Verhoeven 1992: 19), Poland (Buczek 2005: 18), Spain (Braun-Blanquet \& de Bolos 1957: 5, Cirujano 1980: 5, Rivas-Martínez et al. 1980: 5, Conesa 1991: 2), Switzerland (Dengler et al. 2004: 1) (Table 3, 4).

\section{Data analysis}

The classification of the vegetation was conducted by Modified TWINSPAN (Roleček et al. 2009), implemented in the software package JUICE 7.0.102 (Tichý 2002).

To clarify the limiting ecological factors, statistical analysis in the STATISTICA 7.0 software package and JUICE was used. In order to assess the impact of ecofactors and rela- tionship of communities to the main ecological factors, a method of synphytoindication was used with the calculation for each species of vascular plants in all communities (Didukh 2011). Ellenberg indicator values were used for this purpose (Ellenberg et al. 1991). For each species in the relevés, quantitative (point) indicators are calculated for the six most important environmental factors.

The world map of Köppen-Geiger climate classification (Peel et. al. 2007) was used for the confirmation of the association distribution depending on temperature.

The combined synoptic table shows the combination of percentage frequency and modified fidelity index phi coefficient (Tichý 2002). The table shows species with phi values of frequency over 10 . The phi fidelity index was used for diagnostic species identification. Non-essential values of fidelity (less than 0.001 ) were removed on the basis of Fischer's exact test. The fidelity threshold for the allocation of diagnostic species is at least $25 \%$, for highly diagnostic species $-50 \%$.

The Czekanowski-Sørensen coefficient was used for the calculation of floristic similarity:

$K s c=\frac{2 c}{a+b}$,

where $a$ - number of species in first community; $b$ - number of species in second community; c - number of species common to the two communities. The limit values of 
this factor are from 0 to $1, \mathrm{Ksc}=1$ absolute coincidence of floristic lists, Ksc $=0$ they have no common species.

The Stugren-Radulescu coefficient of species composition similarity is calculated by the formula

$K s r=\frac{a+b-3 c}{a+b+c}$.

This coefficient ranges from -1 to +1 , the range from 1 to 0 indicates a similarity, the range from 0 to +1 - shows a difference of floristic lists (Kostina 2013).

For comparison, I analyzed floristic lists (only the species composition) from the relevés and identified clusters based on floristic composition.

The names of syntaxa were used in accordance with the International Code of Phytosociological Nomenclature (Weber et al. 2000). The higher syntaxonomic units are given in the latest prodromes of Europe (Mucina et al. 2016) and Ukraine (Dubyna \& Dziuba 2019). Names of vascular plant species are used in accordance with the recent Ukrainian nomenclatural checklist (Mosyakin \& Fedoronchuk 1999). Only some plant names with doubtful taxonomical status are cited with reference to the relevant sources (e.g. Mavrodiev et al. 2015). The names of the species in the synoptic table are given in accordance with the authors of the original works.

\section{Results and Discussion}

\section{Cladium in Europe: two species or one?}

Cladium mariscus and C. martii are morphologically very similar species. Their main features are: $C$. martii - broad panicle with diffused strongly branched lateral inflorescences, up to $20 \mathrm{~cm}$ in length with numerous elongated twigs, diffused clusters with 3-7(10) spikelets; $C$. mariscus - narrow and compact inflorescence with 5-20(30) spikelets aggregated into dense clusters (Egorova 1976, Danylyk 2011, 2012) (Figure 2).

Both C. mariscus and C. martii are geographically isolated so they may be treated as subspecies of $C$. mariscus. However, our field studies did not confirm a clear geographical correlation with morphological features in Cladium mariscus populations. For example, photographs 1 and 2 were taken on Dzharylhach Island (Ukraine) in different locations about $1200 \mathrm{~m}$ apart. Photo 3 was taken in the Lviv region at the same time. According to the current determination keys (Egorova 1976, Danylyk 2011, 2012), plants from photographs 2 and 3 should be treated as C. mariscus subsp. mariscus and the plant from photograph $1-$ as $C$. martii or $C$. mariscus subsp. martii.

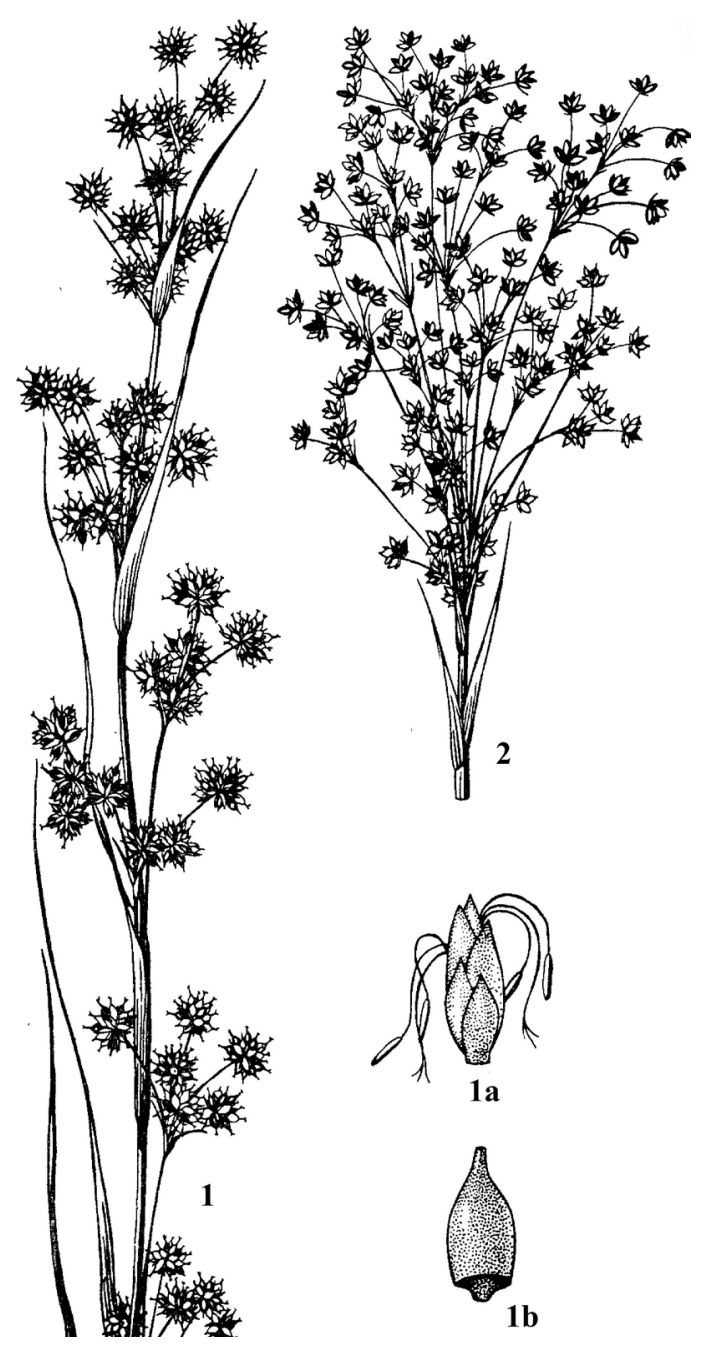

Figure 2: Morphological differences between Cladium mariscus and C. martii (from Egorova 1976, modified by the author): $1-$ C. mariscus: $1 \mathrm{a}$ - spikelet, $1 \mathrm{~b}$ - fruit, 2 - C. martii.

Slika 2: Morfološke razlike med vrstama Cladium mariscus in C. martii (iz Egorova 1976, spremenjeno): 1 - C. mariscus: 1a - klasek, 1b plod, 2 - C. martii.

In addition, herbarium specimens in KW, KWHA and MW from Germany, Italy, Poland, Czech Republic, Latvia, Estonia, Lithuania, Ukraine, Russian Federation, Belarus, Kazakhstan, Kyrgyzstan, Turkey, Azerbaijan and Georgia were analyzed and a similar situation was found: in many different locations both morphotypes ("southern" with diffused inflorescences - Cladium martii-morphotype - and "western" with compact inflorescences Cladium mariscus-morphotype) were identified. Based on these data, I treat Cladium mariscus as one polymorphic species and accept it in the wide sense to include C. martii as a heterotypic synonym of $C$. mariscus. This solution has also been confirmed by several other authors (Castroviejo et al. 2007, Verloove 2012). 

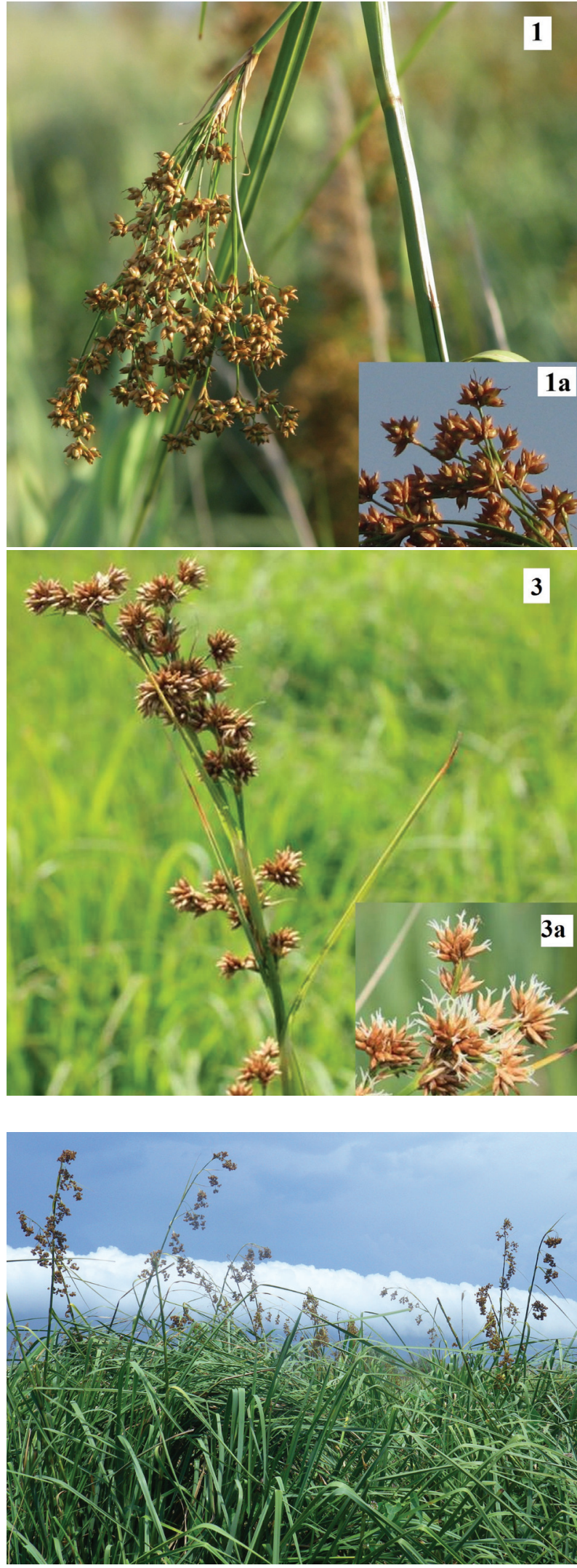

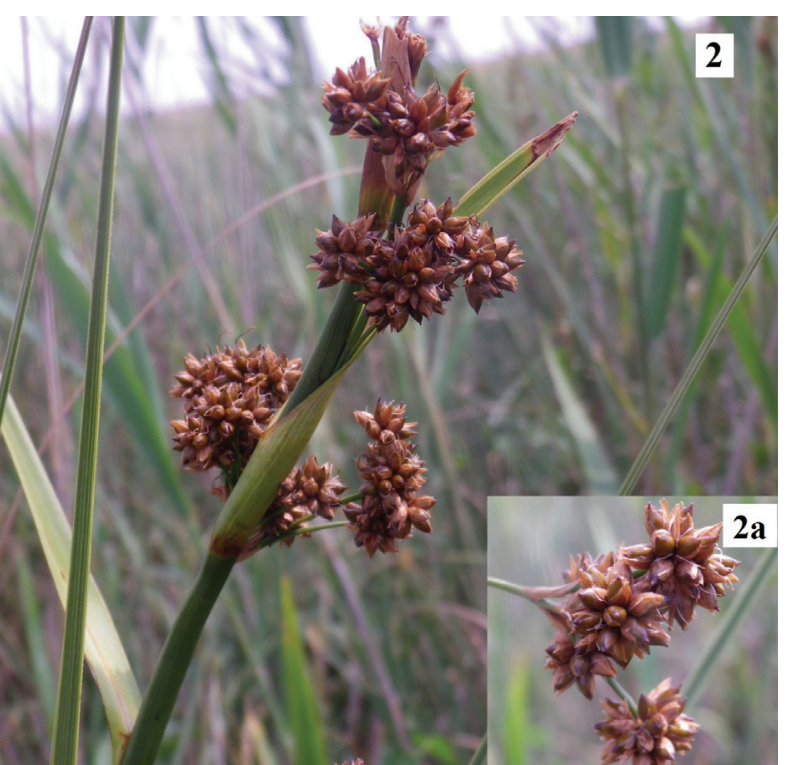

Figure 3: Polymorphism of Cladium mariscus s.l.: 1- photo by D. A. Davydov (4 July 2017), 2 - photo by A. O. Davydova (6 July 2017), both - on Dzharylhach Island, 3 - photo by A. A. Kuzemko (23 June 2017) near Zolochivka River in the Lviv region: 1a, 2a, 3a - enlargements of lateral inflorescences and spikelets, 1, 2, 3-general views of inflorescences of different individuals.

Slika 3: Polimofizem vrste Cladium mariscus s.l.: 1- foto D. A. Davydov (4 julij 2017), 2 - foto A. O. Davydova (6 julij 2017), oboje - na otoku Dzharylhach, 3 - foto A. A. Kuzemko (23 junij 2017) ob reki Zolochivka v regiji Lviv: 1a, 2a, 3a - povečava stranskih cvetov in klaskov, 1, 2, 3- splošni pogled na cvetove različnih primerkov.

\section{Communities with Cladium mariscus in Ukraine}

Cladium mariscus is distributed on calcareous wetlands in western Ukraine and on the banks of freshwater and salty reservoirs of the northern Black Sea Coast (Andrienko-Malyuk \& Dubyna 2009). Based on the differences in ecological conditions of these communities, it would be logical to ensure that it is correct to merge relevés into the same association.

Figure 4: A general view of Cladium mariscus communities on Dzharylhach Island (photo by A. O. D avydova).

Slika 4: Videz združbe z vrsto Cladium mariscus na otoku Dzharylhach (foto A. O. Davydova). 
Cladium mariscus was found by the author in 6 locations (Figure 1) in the central part of Dzharylhach Island. The relevés were made mainly in dune slack habitats, with only a few locations being situated near lakes.

At the first stage, the author analyzed published data devoted to the syntaxonomy of Cladium mariscus communities in Ukraine (Dubyna et al. 2004, Yaschenko \& Turich 2007, Borsukevych 2008, Kuzyarin \& Zhizhin 2008, Datsyuk \& Andrienko 2013, Chorna 2013) and compared the floristic composition with the data of the original relevé of the association Cladietum marisci (Allorge 1921). The floristic composition was identified for all relevés (from western to southern regions) (species occurring in $>50 \%$ of relevés): Cladium mariscus, Phragmites australis, Lycopus europaeus, Lythrum salicaria, Mentha aquatica. So-called "vikarians" were established for the western and southern locations: Schoenus ferrugineus and $S$. nigricans, a group of freshwater sedges (Carex acutiformis, C. nigra, C. spicata) and a group of sedges on salt areas (C. extensa and $C$. distans). The common species from the original relevés (Allorge 1921) and the data from Ukraine are Eupatorium cannabinum, Molinia caerulea, Ranunculus lingua, Schoenoplectus tabemaemontani.

\section{Comparison of Ukrainian and European communities}

The authentic Cladietum marisci relevés were carried out in the north-western part of France, on the limestone plateau on the right bank of the Seine (Allorge 1921). Accordingly, the protologue of this syntaxon refers to continental freshwater habitats, not coastal areas, which differ in both ecological conditions and floristic composition. The group of coastal Cladietum marisci relevés is characterized by poor species composition, lacking a moss layer and the presence of halophytic species.

The next step was therefore to create a database of vegetation relevés with Cladium mariscus. It included selected relevés from various publications and represented by various associations, subassociations and variants with domination of Cladium mariscus. Twenty-two floristic lists from Europaean communities with $C$. mariscus were analysed in STATISTICA and three large clusters were identified combining similar floristic lists: cluster A (freshwater and mostly flooded communities with a large number of aquatic species and mosses, Cladietum marisci sensu stricto); cluster B (communities with low salinization, Soncho maritimi-Cladietum marisci) and cluster C (more salinized communities, Junco maritimi-Cladietum marisci) (Figure 5).

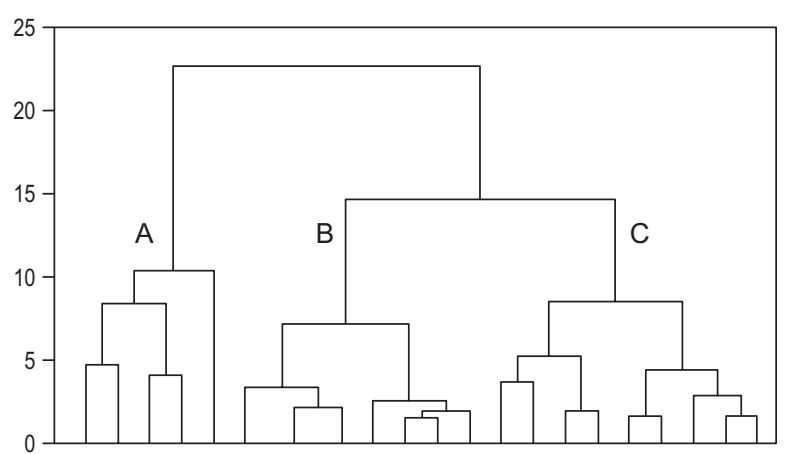

Figure 5: Dendrogram based on floristic lists of communities with Cladium mariscus as dominant species: A - communities with a large number of aquatic species and mosses; $\mathrm{B}$ - communities with low salinization, $\mathrm{C}$ - more salinized communities.

Slika 5: Dendrogram na osnovi florističnih popisov združb z dominantno vrsto Cladium mariscus: A - združbe z velikim številom vodnih vrst; $\mathrm{B}$ - združbe z manjšo slanostjo, C - združbe na bolj slanih rastiščih.

At the lower levels, the clusters were distributed with an aberration: each of three large clusters has uncharacteristic inclusions of untypical communities, since the distribution of the floristic lists was calculated by Euclidean distances, Ward's method, which provides an accurate distribution at the highest levels. However, since the main task was to re-distribute the array of floristic data, the author focused on the allocation of three main clusters.

The next step was to apply the modified TWINSPAN algorithm for the allocation of individual clusters of relevés (Roleček et al. 2009). At this stage, 162 relevés were used for analysis. I selected the most ecologically appropriate distribution of communities to six clusters at the association level (Figure 6). Clusters 1 and 2 represent the association Dorycnio recti-Cladietum marisci Gradstein \& Smittenberg 1977 (Gradstein \& Smittenberg 1977). The distribution into two clusters is due to the presence of two clearly separated variants of the association - for Crete (typical) and for continental Europe. Based on the last critical revisions, the typical Dorycnio recti-Cladietum marisci association belongs to Central and Eastern Mediterranean tall-herb vegetation of Dorycnio recti-Rumicion conglomerati, Convolvuletalia sepium and Epilobietea angustifolii (Gradstein \& Smittenberg 1977, Mucina et al. 2016).

The third cluster is Junco maritimi-Cladietum marisci (Br.-Bl. \& O. de Bolòs 1957) Géhu \& Biondi 1988 described from Italy (eVeg database); the fourth one - Soncho maritimi-Cladietum marisci (Br.-Bl. \& $\mathrm{O}$. de Bolòs 1957) Cirujano 1980 described from Spain. There are now two opinions about the classification of associations: various authors have synonymized them using the priority name Soncho maritimi-Cladietum marisci (eVeg database, 


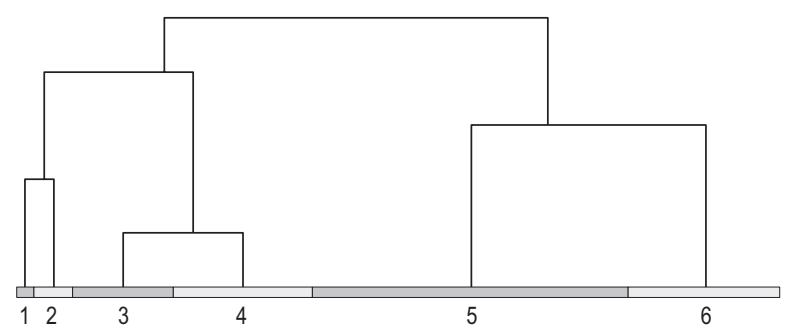

Figure 6: Dendrogram of "similarity-difference" between plant communities with Cladium mariscus as dominant species in Europe: 1,2 - Dorycnio recti-Cladietum marisci; 3 - Junco maritimi-Cladietum marisci; 4 - Cladio marisci-Schoenetum nigricantis, Soncho maritimiCladietum marisci; 5 - Cladietum marisci (terrestrial variant); 6 - Cladietum marisci (water variant).

Slika 6: Dendrogram podobnosti med rastlinskimi združbami na osnovi "razlike v podobnosti" z dominantno vrsto Cladium mariscus v Evropi: 1,2-Dorycnio recti-Cladietum marisci; 3 - Junco maritimiCladietum marisci; 4 - Cladio marisci-Schoenetum nigricantis, Soncho maritimi-Cladietum marisci; 5 - Cladietum marisci (kopenska varianta); 6 - Cladietum marisci (vodna varianta).

Landucci et al. 2020) or recognize both associations in parallel (Taffetani 2011, Pirone 2014, Pirone et al. 2014, Lastrucci et al. 2017, Pedrotti 2018, Habitats Naturels supports de la biodiversité 2018, Habitat Italia 2018). Both of these associations are present on saline soils but Junco maritimi-Cladietum marisci is characterized by the presence of numerous subhalophytic diagnostic species: Bolboschoenus maritimus, Juncus maritimus and Carex extensa. The relevés from Dzharylhach Island are also in cluster 3. Two associations from this cluster also belong to different syntaxa of the higher ranks. The association Junco maritimi-Cladietum marisci belongs to the alliance Scirpion maritimi from the order Bolboschoenetalia maritimi (Biondi et al. 2014, Mucina et al. 2016, Habitat Italia 2018) and the association Soncho maritimi-Cladietum marisci belongs to the alliance Magnocaricion elatae from the order Magnocaricetalia (Rivas-Martínez et al. 2001, Mucina et al. 2016).

Two clusters (5 and 6) are distinguished as separate groups: 5 - Cladietum marisci (terrestrial variant) and 6 - Cladietum marisci (water variant). Cluster 5 includes relevés from western Ukraine. The problem of the separation of these relevés into two variants is based on the flooding degree, but also depends on the technique of plot selection. For example, relevés of the typical Cladietum marisci by H. A. Chorna (Chorna 2013; Borysova \& Chorna 2011) were originally indicated as the association Charetum tenuispinae Dąmbska 1966 ex Tomaszewicz 1979 from the class Charetea intermediae F. Fukarek 1961 and included Schoenus ferrugineus and Cladium mariscus as common species. At the same time, European relevés combine water and coastalwater species in the association Utriculario-Cladietum
(Jeschke 1963) Succow in Knapp et al. 1985 (Verhoeven 1992, Zscheile \& Schubert 2010). There is also a view of the classification of $C$. mariscus communities into successional stages based on paleoecological research in Poland: lake phase, lower peatland phase, upper peatland phase (Gałka \& Tobolski 2012). It is possible that all flooded communities of $C$. mariscus with aquatic plants are the starting point of successional development of a "typical community". It is obvious, though, that these plant communities do not fit the original diagnosis in terms of floristic composition and ecological conditions (Allorge 1921; Dengler et al. 2004).

It was interesting to calculate the floristic similarity between selected clusters, so floristic lists for these clusters were prepared. Cluster analysis was conducted by STATISTICA combining the Dorycnio recti-Cladietum marisci group into a joint cluster (Figure 7).

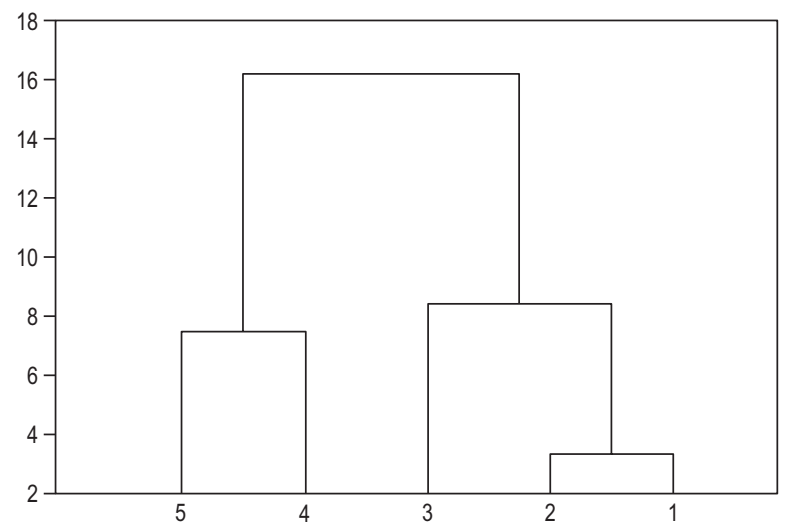

Figure 7: Dendrogram of "similarity-difference" between the plant communities based on floristic composition: 1 - Dorycnio rectiCladietum marisci; 2 - Junco maritimi-Cladietum marisci; 3 - Soncho maritimi-Cladietum marisci; 4 -Cladietum marisci (terrestrial variant); 5 - Cladietum marisci (water variant).

Slika 7: Dendrogram podobnosti med rastlinskimi združbami na osnovi "razlike v podobnosti" z dominantno vrsto Cladium mariscus: 1 - Dorycnio recti-Cladietum marisci; 2 - Junco maritimi-Cladietum marisci; 3 - Soncho maritimi-Cladietum marisci; 4 - Cladietum marisci (kopenska varianta); 5 - Cladietum marisci (vodna varianta).

According to the Czekanowski-Sørensen coefficient (Ksc), the most significant differences were found between the clusters Junco maritimi-Cladietum marisci and terrestrial and water variants of Cladietum marisci and this supports the author's opinion about the difference between communities from western and southern Ukraine. Based on the Stugren-Radulescu coefficient of species composition similarity (Ksr,) clusters Junco maritimi-Cladietum marisci, Dorycnio recti-Cladietum marisci and typical Cladietum marisci have the lowest similarity, too. The two groups that are closest according to floristic composition are: the Mediterranean Junco maritimi-Cladietum marisci and Soncho maritimi-Cladietum marisci, and the Central 
and Eastern European water and terrestrial variants of Cladietum marisci (Table 1).

Table 1: Indices of coefficients of species composition similarity (1 - Dorycnio recti-Cladietum marisci; 2 -Junco maritimiCladietum marisci; 3 - Soncho maritimi-Cladietum marisci; 4

- Cladietum marisci (terrestrial variant); 5 - Cladietum marisci (water variant).

Tabela 1: Indeksi podobnosti vrstne sestave (1 - Dorycnio recti-Cladietum marisci; 2 - Junco maritimi-Cladietum marisci; 3 - Soncho maritimi-Cladietum marisci; 4 - Cladietum marisci (kopenska varianta); 5 - Cladietum marisci (vodna varianta).

\begin{tabular}{cccccc}
\hline Ksr & 1 & 2 & 3 & 4 & 5 \\
1 & - & 0.1 & 0.14 & 0.12 & 0.07 \\
2 & 0.78 & - & 0.22 & 0.05 & 0.09 \\
3 & 0.64 & 0.49 & - & 0,14 & 0.1 \\
4 & 0.73 & 0.88 & 0.69 & - & 0.22 \\
5 & 0.84 & 0.82 & 0.77 & 0.2 & - \\
\hline
\end{tabular}

The floristic composition similarity between the associations Junco maritimi-Cladietum marisci and Soncho maritimi-Cladietum marisci was 0.49 for the StugrenRadulescu and 0.22 for the Czekanowski-Sørensen coefficients. The overall floristic similarity of these two clusters is therefore about $25 \%$. In the author's opinion, these coefficients for two associations from the same climatic region cannot indicate their identity.

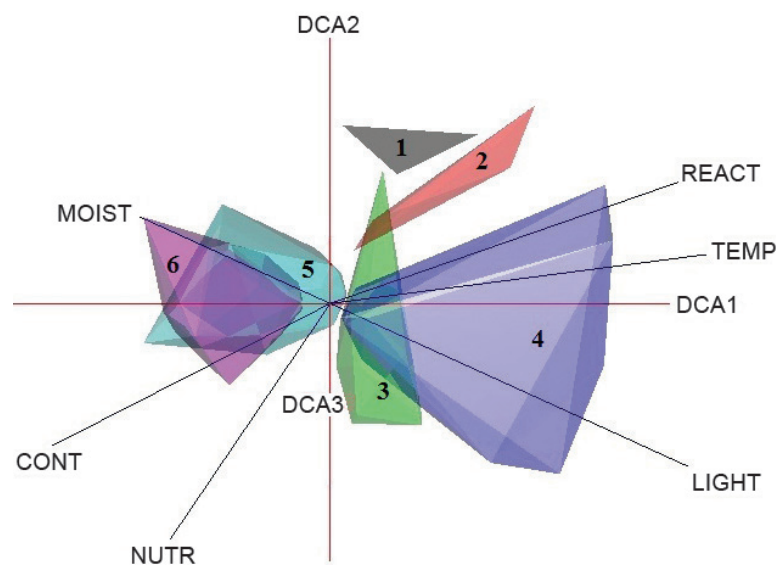

Figure 8: Results of DCA ordination of the studied communities: 1, 2 - Dorycnio recti-Cladietum marisci; 3 - Junco maritimi-Cladietum marisci; 4 - Soncho maritimi-Cladietum marisci; 5 - Cladietum marisci (terrestrial variant); 6 - Cladietum marisci (water variant). Values: MOIST - moisture; NUTR - nutrients; REACT - soil reaction; LIGHT - light; TEMP - temperature; CONT - continentality. Slika 8: Rezultati DCA ordinacije obravnavanih združb: 1, 2 - Dorycnio recti-Cladietum marisci; 3 - Junco maritimi-Cladietum marisci; 4 - Soncho maritimi-Cladietum marisci; 5 - Cladietum marisci (kopna varianta); 6 - Cladietum marisci (vodna varianta). Values: MOIST vlažnost; NUTR - hranila; REACT - reakcija tal; LIGHT - svetloba; TEMP - toplota; CONT - kontinentalnost.
In order to find the differentiation of the most important ecological factors, DCA-analysis was applied using ecological indicator values (Ellenberg et al. 1991). These results show that the most ecologically isolated is the Dorycnio recti-Cladietum marisci association. The most important factors for Junco maritimi-Cladietum marisci and Soncho maritimi-Cladietum marisci are soil reaction, light and temperature values. The ecological amplitude of the terrestrial variant of Cladietum marisci almost completely overlaps with the amplitude of the water variant. This ecological differentiation is determined by the level of soil moisture and the continentality of the climate.

The differentiation of the associations in relation to the level of light showed that the highest values for this indicator value are observed in Dorycnio recti-Cladietum marisci and Junco maritimi-Cladietum marisci. Water and terrestrial variants of Cladietum marisci are represented by lower values of light, which can be explained by the division of association habitats into coastal territories and continental ones (Figure 9).

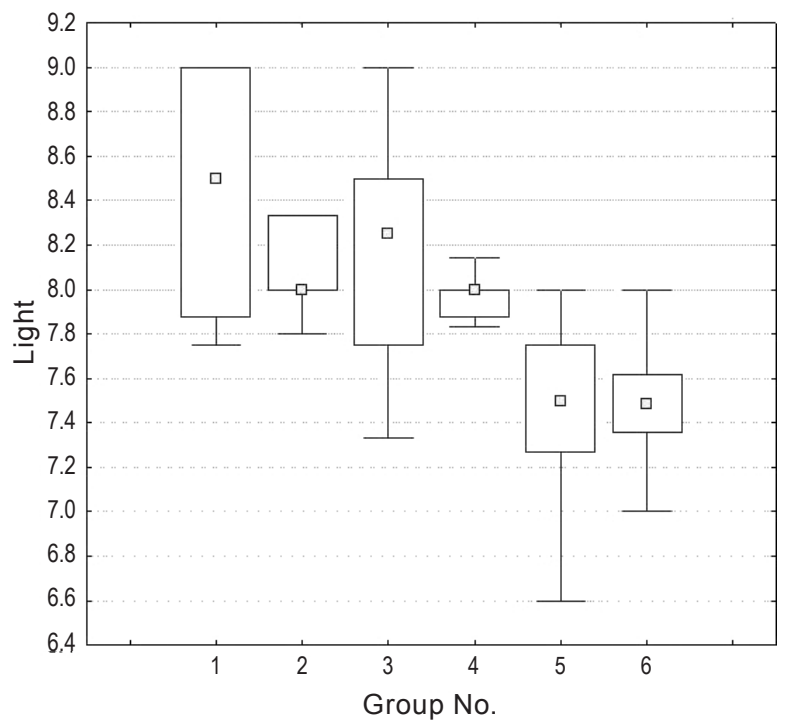

Figure 9: Differentiation of the associations based on light values. Numbers along the abscissa axis correspond to the number of associations in Figure 8.

Slika 9: Razlike med asociacijami na osnovi vrednosti indeksa svetlobe. Številke ob abscisi odgovarjajo številkam asociacij na Sliki 8.

Differentiation of the associations based on temperature regime is presented by three groups according to the World Map of Köppen-Geiger Climate Classification (Peel et. al. 2007): Dorycnio recti-Cladietum marisci in the typical hot-summer mediterranean climate type (Csa), Junco maritimi-Cladietum marisci and Soncho maritimiCladietum marisci partially represented in the hot-summer mediterranean climate, the warm-summer mediterranean climate and in the hot-summer humid continental cli- 
mate types (Csa, Csb, Dfa). The water and terrestrial variants of Cladietum marisci are mostly found in the temperate oceanic and warm-summer humid continental climate types (Cfb, Dfb) (Figure 10). This pattern is also observed in the graph with continentality values: Dorycnio rectiCladietum marisci tends to the oceanic type, Junco maritimi-Cladietum marisci and Soncho maritimi-Cladietum marisci tend to the suboceanic types, the terrestrial variant of Cladietum marisci has fairly wide amplitude from the oceanic to the suboceanic type, the water variant of Cladi-

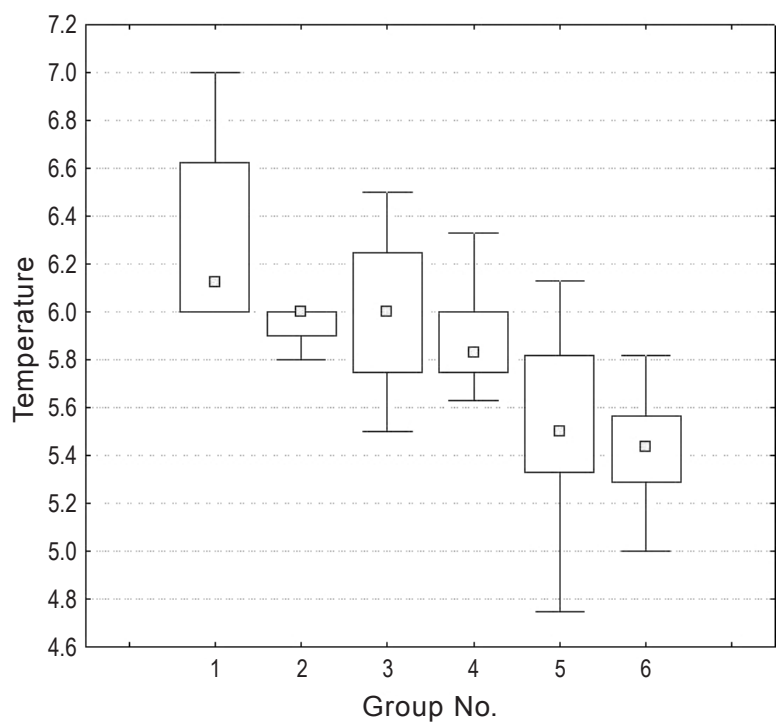

Figure 10: Differentiation of the associations based on temperature values.

Figure 10: Razlike med asociacijami na osnovi vrednosti indeksa toplote.

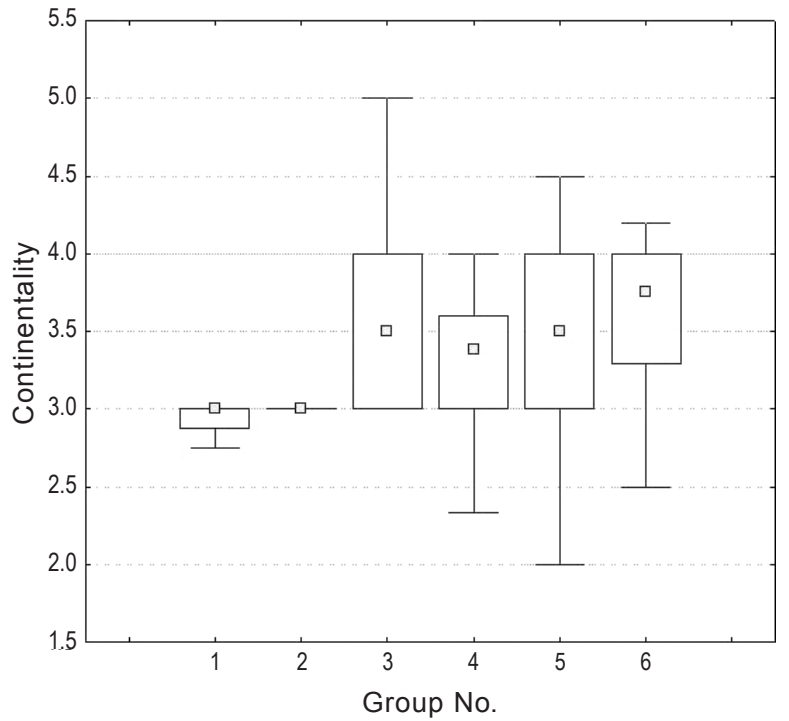

Figure 11: Differentiation of the associations based on continentality values.

Figure 11: Razlike med asociacijami na osnovi vrednosti indeksa kontinentalnosti. etum marisci tends to the suboceanic type. The amplitude of the typical Cladietum marisci can be explained by the wide distribution of this syntaxon (Figure 11).

The moisture factor demonstrates a great difference between hydrophilous and more xerophytic associations of Dorycnio recti-Cladietum marisci. Junco maritimi-Cladietum marisci is the most xerophytic of all the studied syntaxa. Other associations tend to temporarily flooded places (Figure 12).

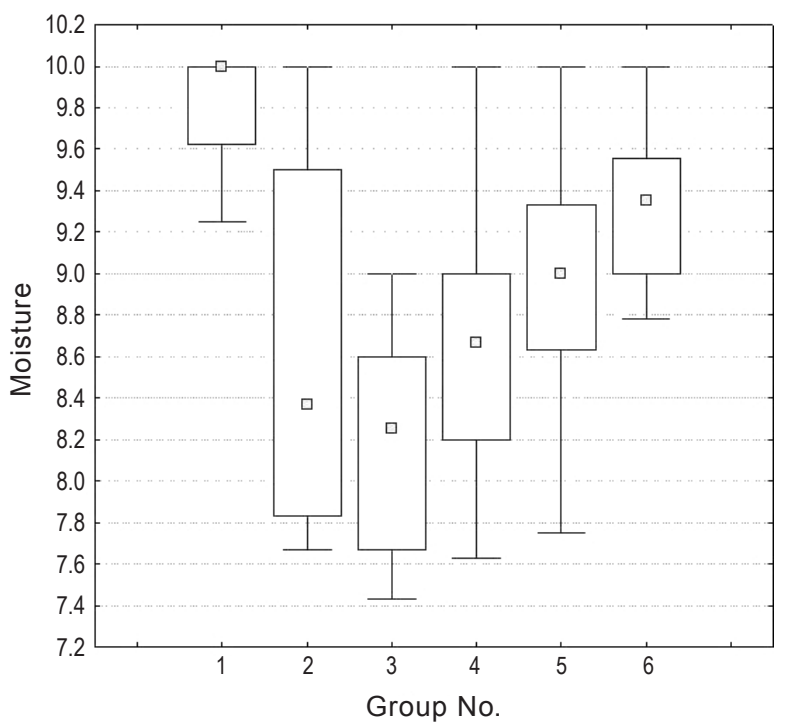

Figure 12: Differentiation of the associations based on moisture values. Figure 12: Razlike med asociacijami na osnovi vrednosti indeksa vlažnosti.

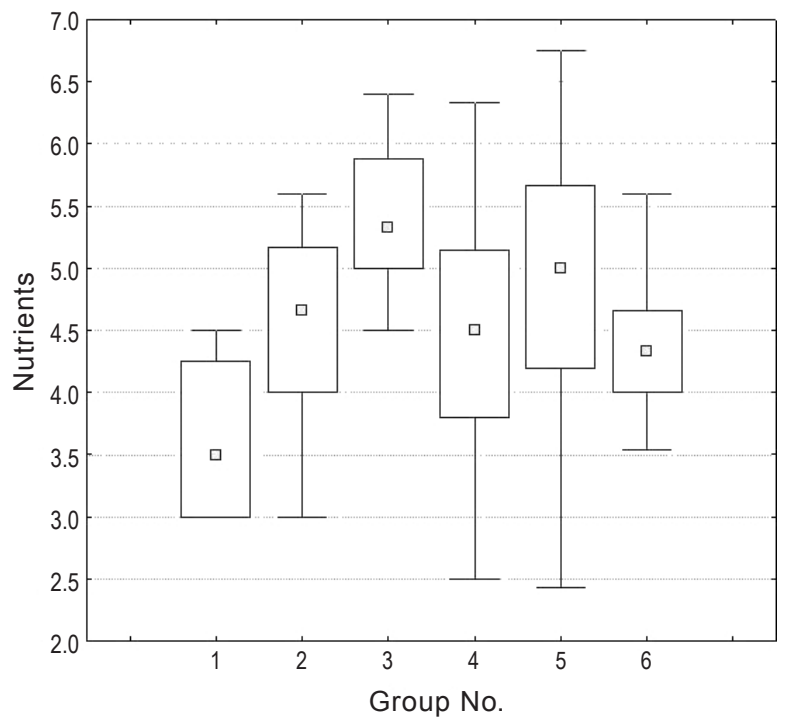

Figure 13: Differentiation of the associations based on nutrient values. Figure 13: Razlike med asociacijami na osnovi vrednosti indeksa hranil. 
Differentiation of the associations based on the nutrient content in soils indicates a significant differentiation: water Dorycnio recti-Cladietum marisci is marked by the lowest trophic level and the typical by a moderate level. The broadest amplitude is observed in typical (terrestrial) Cladietum marisci and in Soncho maritimi-Cladietum marisci. Junco maritimi-Cladietum marisci tends to soils that are moderately rich in nutrients (Figure 13).

Differentiation of the associations based on soil reaction showed that the highest alkaline reaction is observed in Dorycnio recti-Cladietum marisci associations. The communities of Junco maritimi-Cladietum marisci grow on slightly alkaline soils. Values of the typical Cladietum marisci range from neutral to carbonate soils. Water Cladietum marisci is closer to neutral soils. Values for Soncho maritimi-Cladietum marisci also indicate the predominance of carbonates in soils (Figure 14).

As a result of this analysis, I propose recognition of these syntaxa dominated by Cladium mariscus: Cladietum marisci Allorge 1921, Soncho maritimi-Cladietum marisci (Br.-Bl. \& O. de Bolòs 1957) Cirujano 1980, Dorycnio recti-Cladietum marisci Gradstein \& Smittenberg 1977 and Junco maritimi-Cladietum marisci (Br.-Bl. \& O. de Bolòs 1957) Géhu \& Biondi 1988. I believe that Cladio marisci-Schoenetum nigricantis sensu Lájer 2006 non Soó 1930 is a synonym of Soncho maritimi-Cladietum marisci. The most controversial associations Soncho maritimiCladietum marisci and Junco maritimi-Cladietum marisci are recognized as separate, based on floristic comparison and ecological analysis. The merging of these syntaxa into

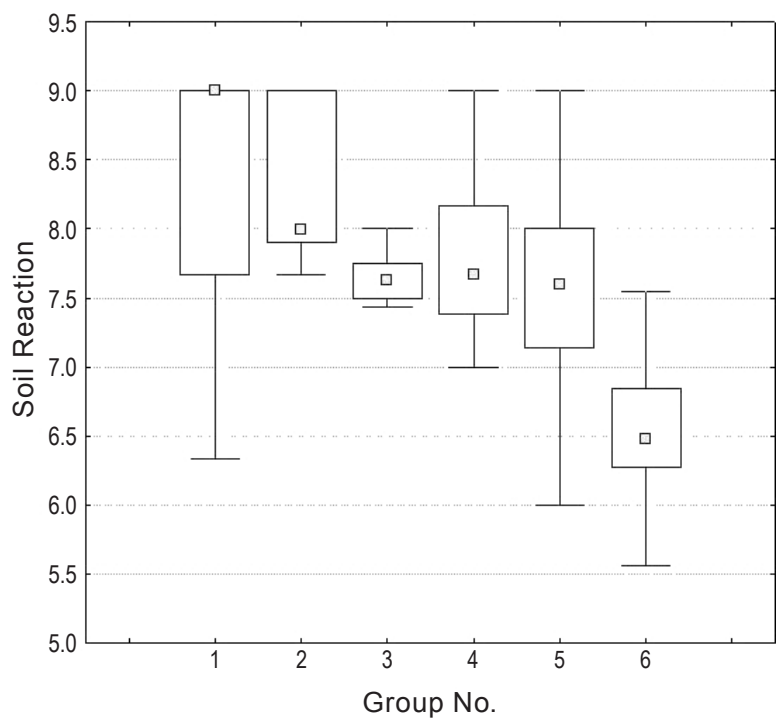

Figure 14: Differentiation of the associations based on soil reaction values.

Figure 14: Razlike med asociacijami na osnovi vrednosti indeksa reakcije tal. one was proposed recently by Landucci et al. (2020), but this was probably due to the small number of relevés with Juncus maritimus used in that study. The association Junco maritimi-Cladietum marisci is new for Ukraine from the Dzharylhach Island. Its special feature is the presence of Poacynum russanovii (Mavrodiev et al. 2015) (Table 2), an endemic species for this island. The following syntaxonomic scheme for communities with Cladium mariscus for "Dzharylhatskyi" National Nature Park is proposed: Phragmito-Magnocaricetea Klika in Klika \& Novák 1941

Bolboschoenetalia maritimi Hejný in Holub et al. 1967

Scirpion maritimi Dahl \& Hadač 1941

Junco maritimi-Cladietum marisci (Br.-Bl. \& O. de Bolòs 1957) Géhu \& Biondi 1988

Diagnostic species of this association: Carex distans, Cladium mariscus, Juncus maritimus, Mentha aquatica, Phragmites australis, Poacynum russanovii, Pulicaria dysenterica.

Constant species: Elytrigia elongata.

Dominant species: Cladium mariscus, Phragmites australis.

In relation to the order Bolboschoenetalia maritimi as part of Phragmito-Magnocaricetea (Biondi et al. 2014, Mucina et al. 2016), the author does not agree with the separation of the class Bolboschoenetea maritimi Tx. \& Vicherek in Tx. \& Hülbusch 1971 that is widely accepted in many Ukrainian papers (Dubyna et al. 2007, Dziuba 2008).

As a result of the studied communities, a distribution map of the syntaxa and their types (holotype and neotype) is proposed (Figure 15). Two syntaxa - Cladietum marisci and Junco maritimi-Cladietum marisci - are thus distributed in Ukraine. In the southern part of Ukraine Cladium mariscus grows on the territory of the "Danube Biosphere Reserve" in the Odesa region and also on the "Chornomorsky Biosphere Reserve". Based on the floristic composition of relevés in the synoptic table from the Danube delta (Dubyna et al. 2004), the author considers them to be Cladietum marisci, although these communities need further investigation. The map shows the essential distance $(1358 \mathrm{~km}$ ) between the locus typicus of Junco maritimi-Cladietum marisci and the location of the syntaxon indicated by the author. The Mediterranean climate partly explains the closeness of Junco maritimiCladietum marisci and Soncho maritimi-Cladietum marisci areas, but what is the explanation in this case? Based on floristic studies, Illichevskyi (1941) put forward a hypothesis about the origin of Dzharylhach Island as "a kind of relic of the former land" and extrapolated the results of geological surveys, observing that the flora of the island partly consists of rare species with Mediterranean and disjunctive areal characteristics typical of the Crimean Peninsula, the Balkans, the Caucasus and Asia Minor. Il- 
Table 2: Phytocoenological table of assotiation Junco maritimi-Cladietum marisci.

Tabela 2: Fitocenološka tabela acociacije Junco maritmi-Cladietum marisci.

\begin{tabular}{|c|c|c|c|c|c|c|c|c|c|c|c|c|}
\hline Releve’s № & 1 & 2 & 3 & 4 & 5 & 6 & 7 & 8 & 9 & 10 & Constancy & Phi coeff. \\
\hline Releve's area $\left(\mathrm{m}^{2}\right)$ & 25 & 25 & 50 & 50 & 30 & 50 & 50 & 70 & 15 & 50 & & \\
\hline Number of species & 9 & 7 & 9 & 9 & 8 & 8 & 9 & 4 & 7 & 8 & & \\
\hline Total cover $(\%)$ & 80 & 90 & 90 & 80 & 90 & 100 & 100 & 90 & 90 & 100 & & \\
\hline \multicolumn{13}{|c|}{ D. s. for the ass. Junco maritimi-Cladietum marisci } \\
\hline Cladium mariscus & 3 & 3 & 2 & 2 & 5 & 5 & 5 & 5 & 2 & 5 & $\mathrm{~V}$ & 100 \\
\hline Juncus maritimus & 2 & + & + & . & 2 & 2 & 2 & . & 3 & . & IV & 78.2 \\
\hline Carex distans & + & . & + & 2 & 2 & $\mathrm{r}$ & . & . & . & + & III & 72.1 \\
\hline Poacynum russanovii & . & . & $\mathrm{r}$ & 2 & . & $\mathrm{r}$ & $\mathrm{r}$ & . & + & . & III & 65.5 \\
\hline \multicolumn{13}{|c|}{ D. s. for the cl. Phragmito-Magnocaricetea } \\
\hline Mentha aquatica & + & 2 & 2 & . & + & . & . & + & . & 2 & III & 78.2 \\
\hline Phragmites australis & 2 & 2 & 3 & + & 2 & 3 & 2 & 2 & 2 & 1 & $\mathrm{~V}$ & 50.8 \\
\hline Pulicaria dysenterica & + & . & + & . & 2 & . & . & + & . & . & III & 58.3 \\
\hline Althaea officinalis & . & + & . & . & . & . & . & . & . & . & I & 28.7 \\
\hline Calystegia sepium & . & . & . & . & . & . & $\mathrm{r}$ & . & . & + & I & 40.8 \\
\hline \multicolumn{13}{|l|}{ Other species } \\
\hline Apera maritima & . & . & . & . & . & . & . & . & + & . & I & - \\
\hline Calamagrostis epigejos & . & + & + & . & + & . & . & . & . & . & II & - \\
\hline Carex extensa & . & . & $\cdot$ & + & . & . & . & . & . & . & I & 28.7 \\
\hline Cirsium alatum & + & . & $\cdot$ & $\mathrm{r}$ & . & . & $\mathrm{r}$ & . & . & . & III & 45.1 \\
\hline Cynanchum acutum & 2 & . & . & . & . & . & . & . & . & . & I & - \\
\hline Elytrigia elongata & + & 2 & . & + & . & $\mathrm{r}$ & $\mathrm{r}$ & . & 2 & . & IV & 45.4 \\
\hline Festuca pratensis & . & . & $\cdot$ & . & + & . & . & . & . & . & I & 28.7 \\
\hline Heracleum sibiricum & . & . & . & . & . & . & $\mathrm{r}$ & . & . & . & I & 28.7 \\
\hline Inula salicina subsp. aspera & . & . & $\cdot$ & + & . & . & $\mathrm{r}$ & . & . & 2 & II & - \\
\hline Limonium gmelinii & . & . & $\cdot$ & . & . & $\mathrm{r}$ & . & . & + & . & II & - \\
\hline Lythrum virgatum & . & . & . & . & . & . & . & . & . & + & I & - \\
\hline Plantago cornuti & . & . & . & $\mathrm{r}$ & . & . & . & . & . & . & I & - \\
\hline Plantago maxima & . & . & . & . & . & + & . & . & . & . & I & 28.7 \\
\hline Schoenus nigricans & . & . & . & . & . & . & . & . & . & + & I & \\
\hline Thalictrum minus & . & . & + & . & . & . & . & . & . & + & I & - \\
\hline
\end{tabular}

\section{Localities:}

1 - N 4601' 543", E 32०94' 92" (09. 07. 2017);

$2-\mathrm{N} 46^{\circ} 01^{\prime} 578^{\prime \prime}, \mathrm{E} 32^{\circ} 93^{\prime} 535^{\prime \prime}$ (09. 07. 2017);

3 - N 4601' 517", E 32 94' 677" (09. 07. 2017);

4 - Island Dzharylhach, D. Dubyna (05. 2002);

5 - N 4601' 472", E $32^{\circ} 93^{\prime} 683^{\prime \prime}$ (09. 07. 2017);

6 - Island Dzharylhach, D. Dubyna (09. 2000);

7 - Island Dzharylhach, D. Dubyna (09. 2000);

8 - N 46 01' 217", E 33 02' 627" (09. 07. 2017);

9- N 460 01' 543", E $32^{\circ} 94^{\prime} 92^{\prime \prime}$ (09. 07. 2017);

10 - Island Dzharylhach, D. Dubyna (05. 2001). lichevskyi concludes that Dzharylhach was originally part of a larger territory connected with the Crimea, Balkans and Asia Minor (Illichevskyi 1941). This idea was also confirmed by later research by geologists (Ryan et al. 1997). Barbarych (1962) believed that the distribution of the genus Cladium in the past tended to the sea coasts, so its growth in the Eastern and Central Europe is also due to the presence of sea basins. The age of origin of southern Ukrainian localites is Pleistocene and western Ukrainian - Miocene (Barbarych 1962).
Cladium mariscus therefore has a disjunct habitat. The existence of individual localities of $C$. mariscus with halophilic elements is due to regional features - soil type, salinization and flooding.

Cladium mariscus s.l. is a key species in the habitats from Habitat Directive "7210 Calcareous fens with Cladium mariscus and species of the Caricion davallianae" (Interpretation Manual of European Union Habitats 2013) and in "D 5.2 Large thickets without free standing water" of Resolution No. 4 of the Bern Convention (2016) 


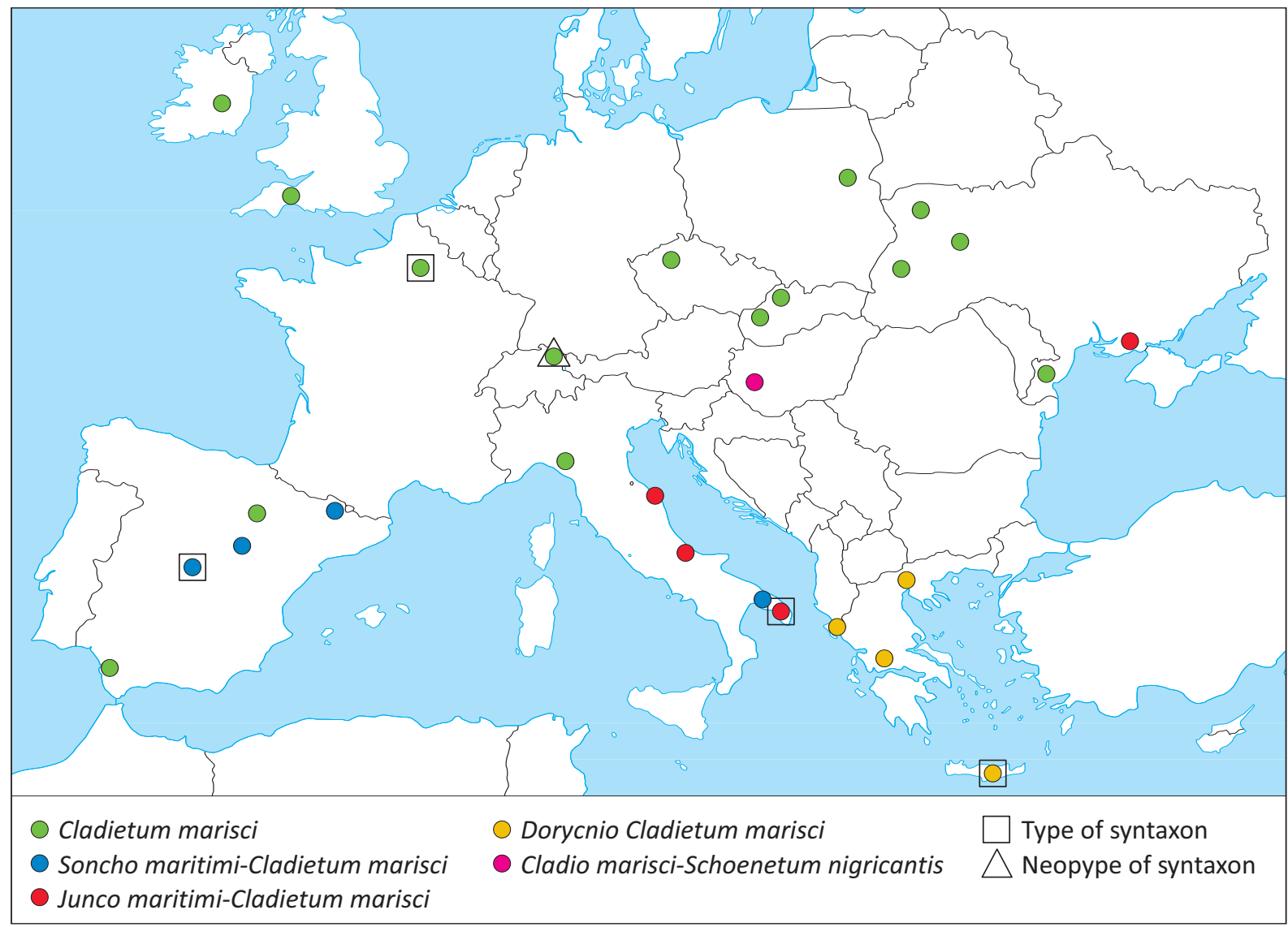

Figure 15: Map of syntaxa based on the results of this study.

Slika 15: Zemljevid sintaksonov na osnovi rezultatov te raziskave.

(Perrino et al. 2013, Detailed final conclusions ... 2016, Habitats Naturels supports de la biodiversité 2018, Habitat Italia 2018). We propose distinguishing a new sub-type of habitat D 5.2 "Large thickets without free standing water" ("D 5.2.1. Halophytic wetlands and wet depressions with Cladium mariscus").

\section{Conclusions}

The isolated position of plant communities with Cladium mariscus s.l. on Dzharylhach Island was thus confirmed on the basis of the results of the analysis of geobotanical relevés. A new subtype of habitat ("D 5.2.1. Halophytic wetlands and wet depressions with Cladium mariscus") is proposed. The name "Cladio marisci-Schoenetum nigricantis sensu Lájer 2006 non Soó 1930" is a synonym of Soncho maritimi-Cladietum marisci. The floristic and ecological independence of Soncho maritimi-Cladietum marisci (Br.-Bl. \& Bolòs 1957) Cirujano 1980 is sub- stantiated. A new association Junco maritimi-Cladietum marisci (Br.-Bl. \& Bolòs 1957) Géhu \& Biondi 1988 for vegetation of Ukraine was confirmed. Further research of Cladium mariscus communities is needed, particularly a comparison with data from the Caucasus and Western Asia.

\section{Acknowledgements}

The autor are very grateful to editor in chief Urban Šilc and two anonymous reviewers for comments and recommendations that greatly improved the manuscript. Special thanks are due to Denis Davydov and Martin Cregeen for English proofreading, to Dmytro Dubyna for providing the relevés and to Anna Kuzemko for providing images.

Anastasia Davydova (D, https://orcid.org/0000-0001-7839-962X 
Table 3: Data about the geobotanical relevés included in the database.

Tabela 3: Podatki o vegetacijskh popisih vključenih v podatkovno bazo.

\begin{tabular}{|c|c|c|c|}
\hline Syntaxa & Country & Year & № of table/releve \\
\hline \multirow[t]{9}{*}{ Cladietum marisci } & Spain & 1957 & tab. 15 , rel. $1-5$ \\
\hline & Great Britain & 1980 & tab. 3, rel. 2 \\
\hline & Ireland & 1990 & tab. 2, rels. 16-29 \\
\hline & Netherlands & 1992 & tab. 4, rels. $1-19$ \\
\hline & Poland & 2005 & tab. 1 , rels. $10-18$ \\
\hline & Croatia & 2010 & tab. 3, rels. 24-34 \\
\hline & Ukraine & 2013 & tab. 31, rels. $1-10$ \\
\hline & Ukraine & 2013 & p. $10-11$ \\
\hline & Italy & 2017 & tab. 8 , rels. $1-8$ \\
\hline Cladietum marisci var. Carex elata & Poland & 2005 & tab. 1 , rels. $1-9$ \\
\hline \multirow[t]{3}{*}{ Soncho maritimi-Cladietum marisci } & Italy & 1980 & tab. 4 , rels. $1-3$ \\
\hline & Spain & 1980 & tab. 7 , rels. $1-5$ \\
\hline & Italy & 1991 & tab. 7 , rels. $1-2$ \\
\hline Soncho maritimi-Cladietum marisci myrtetosum communis & Italy & 2006 & tab. 4, rels. 4-6 \\
\hline Soncho maritimi-Cladietum marisci schoenetosum nigricantis & Spain & 1980 & tab. 7 , rels. $10,12,14,17,19$ \\
\hline \multirow[t]{4}{*}{ Junco maritimi-Cladietum marisci } & Italy & 1988 & rels. $1-5$ \\
\hline & Italy & 1994 & tab. 70 p. 120 \\
\hline & Italy & 2011 & tab. 15 , rels. $3-4$ \\
\hline & Ukraine & $2000-2018$ & in abstract \\
\hline \multirow[t]{2}{*}{ Dorycnio-Cladietum marisci typicum } & Crete & 1977 & tab. 6 , rels. $12-17$ \\
\hline & Greece & 2006 & tab. 2, rels. $16-27$ \\
\hline Dorycnio-Cladietum marisci inops & Crete & 1977 & tab. 6 , rels. $18-25$ \\
\hline Cladio marisci-Schoenetum nigricantis & Hungary & 2006 & tab. 2 , rels. $16-19$ \\
\hline Schoeno nigricantis-Erianthetum ravennae cladietosum marisci & Italy & 2006 & tab. 7 , rels. $1-4$ \\
\hline
\end{tabular}

Table 4: Synoptic table with percentage frequency and modified fidelity index phi coefficient.

Table 4: Sinoptična tabela s frekvencami v odstotkih in modificiranim fi koeficientom navezanosti.

\begin{tabular}{|c|c|c|c|c|c|c|}
\hline Group Number & 1 & 2 & 3 & 4 & 5 & 6 \\
\hline Number of relevés & 4 & 8 & 21 & 29 & 66 & 32 \\
\hline Phragmites australis & . & . & 67 & 39 & 62 & $91^{39.7}$ \\
\hline Cladium mariscus & 100 & 100 & 100 & 100 & 100 & 100 \\
\hline Carex lasiocarpa & . & . & . & . & 2 & $62^{73.1}$ \\
\hline Lythrum salicaria & . & . & 5 & 28 & 26 & $59^{44.8}$ \\
\hline Carex elata & . & . & . & . & 2 & $53^{68.4}$ \\
\hline Galium palustre & . & . & 5 & . & 5 & $50^{60.1}$ \\
\hline Lysimachia vulgaris & . & . & . & 3 & $33^{27.3}$ & $41^{37}$ \\
\hline Peucedanum palustre & . & . & . & . & 3 & $41^{57.4}$ \\
\hline Comarum palustre & . & . & . & . & 2 & $38^{56.2}$ \\
\hline Utricularia vulgaris & . & . & . & $24^{20.4}$ & . & $38^{40.1}$ \\
\hline Calliergonella cuspidata & . & . & . & . & 2 & $34^{53.5}$ \\
\hline Scorpidium scorpioides & . & . & . & . & . & 34 \\
\hline Utricularia minor & . & . & . & . & 2 & $31^{50.8}$ \\
\hline Menyanthes trifoliata & . & . & . & . & . & $28^{49.6}$ \\
\hline Mentha aquatica & & 50 & 38 & 28 & 35 & 25 \\
\hline Juncus subnodulosus & . & . & . & 21 & 5 & $25^{26.8}$ \\
\hline Nymphaea alba & . & . & . & . & . & $25^{46.6}$ \\
\hline Equisetum fluviatile & . & . & . & . & 9 & $25^{37.3}$ \\
\hline Calliergon cuspidatus & . & . & . & . & 2 & $25^{44.8}$ \\
\hline
\end{tabular}




\begin{tabular}{|c|c|c|c|c|c|c|}
\hline Group Number & 1 & 2 & 3 & 4 & 5 & 6 \\
\hline Number of relevés & 4 & 8 & 21 & 29 & 66 & 32 \\
\hline Carex buxbaumii & . & . & . & . & 2 & $22^{41.5}$ \\
\hline Campylium stellatum & . & . & . & . & . & $19^{40.2}$ \\
\hline Lycopus europaeus & . & . & . & 10 & 14 & 19 \\
\hline Lemna minor & . & . & . & . & 2 & $19^{38.1}$ \\
\hline Salix cinerea & . & . & . & . & 3 & $19^{36.2}$ \\
\hline Lysimachia thyrsiflora & . & . & . & . & 3 & $16^{32.2}$ \\
\hline Potentilla palustris & . & . & . & . & 2 & $16^{34.3}$ \\
\hline Epilobium palustre & . & . & . & . & 6 & $16^{28.8}$ \\
\hline Drepanocladus revolvens & . & . & . & . & . & $16^{36.6}$ \\
\hline Stachys palustris & . & . & . & . & 2 & $16^{34.3}$ \\
\hline Lemna gibba & . & . & . & . & . & $12^{32.6}$ \\
\hline Thelocarpon pallidum & . & . & . & . & 3 & $12^{27.9}$ \\
\hline Chara species & . & . & . & . & 3 & $12^{27.9}$ \\
\hline Lathyrus palustris & . & . & . & . & . & $12^{32.6}$ \\
\hline Galium uliginosum & . & . & . & . & . & $12^{32.6}$ \\
\hline Spirodela polyrhiza & . & . & . & . & . & $12^{32.6}$ \\
\hline Poa palustris & . & . & . & . & . & $12^{32.6}$ \\
\hline Carex rostrata & . & . & . & . & 2 & $12^{30.1}$ \\
\hline Eupatorium cannabinum & . & . & . & . & $23^{37.3}$ & 6 \\
\hline Solanum dulcamara & . & . & . & . & $15^{27.9}$ & 6 \\
\hline Typha angustifolia & . & . & 5 & . & $18^{27.7}$ & 6 \\
\hline Schoenus nigricans & . & . & 14 & $72^{69.6}$ & 2 & 6 \\
\hline Agrostis stolonifera & . & . & . & $17^{27.9}$ & 3 & 6 \\
\hline Typha angustata & 25 & . & . & . & 2 & 3 \\
\hline Hydrocotyle vulgaris & 25 & . & . & . & 3 & 3 \\
\hline Iris pseudacorus & . & $50^{62.4}$ & . & . & 3 & 3 \\
\hline Carex panicea & . & . & . & . & $11^{24.9}$ & 3 \\
\hline Holoschoenus romanus & . & 12 & . & 3 & . & . \\
\hline Carex hispida & 25 & 25 & . & $21^{12.4}$ & . & . \\
\hline Linum maritimum & . & . & . & $14^{34.3}$ & . & . \\
\hline Saccharum ravennae & . & . & . & $17^{38.5}$ & . & . \\
\hline Equisetum ramosissimum & . & 12 & . & 3 & . & . \\
\hline Rubus ulmifolius & . & . & . & $17^{38.5}$ & . & . \\
\hline Carex distans & . & 25 & $29^{29.1}$ & 3 & . & . \\
\hline Pulmonaria dacica & $25^{46.6}$ & . & . & . & . & . \\
\hline Arundo donax & $75^{84.5}$ & . & . & . & . & . \\
\hline Polypogon monspeliensis & $25^{46.6}$ & . & . & . & . & . \\
\hline Galium constrictum & 25 & 12 & 5 & . & . & . \\
\hline Nerium oleander & . & 12 & . & . & . & . \\
\hline Anagallis tenella & . & 12 & . & . & . & . \\
\hline Sonchus glaucescens & . & 12 & . & . & . & . \\
\hline Panicum repens & . & $25^{46.6}$ & . & . & . & . \\
\hline Rubus sanctus & . & $38^{57.7}$ & . & . & . & . \\
\hline Oenanthe pimpinelloides & 25 & $62^{60}$ & . & . & . & . \\
\hline Poa trivialis s. sylvicola & . & $25^{46.6}$ & . & . & . & . \\
\hline Juncus heldreichianus & 25 & $38^{39.6}$ & . & . & . & . \\
\hline Rumex conglomeratus & . & $25^{46.6}$ & . & . & . & . \\
\hline Agrostis semiverticillata & $25^{34.6}$ & 12 & . & . & . & . \\
\hline Lythrum junceum & 50 & $25^{16.9}$ & . & . & . & . \\
\hline Imperata cylindrica & $25^{50.7}$ & $25^{27.0}$ & . & . & . & . \\
\hline Cynodon dactylon & . & 12 & . & . & . & . \\
\hline
\end{tabular}




\begin{tabular}{|c|c|c|c|c|c|c|}
\hline Group Number & 1 & 2 & 3 & 4 & 5 & 6 \\
\hline Number of relevés & 4 & 8 & 21 & 29 & 66 & 32 \\
\hline Inula viscosa & . & 25 & . & $28^{29.8}$ & . & . \\
\hline Ipomoea sagittata & . & . & 5 & $31^{47.3}$ & . & . \\
\hline Myrtus communis & . & . & . & $24^{45.8}$ & . & . \\
\hline Phillyrea media & . & . & . & $14^{34.3}$ & . & . \\
\hline Sonchus maritimus & . & . & 10 & $45^{55.7}$ & . & . \\
\hline Oenanthe lachenalii & . & . & 5 & $34^{50.5}$ & . & . \\
\hline Juncus acutus & . & . & $14^{26.1}$ & 7 & . & \\
\hline Juncus articulatus & . & 12 & . & . & . & . \\
\hline Gaudinia fragilis & . & 12 & . & . & . & . \\
\hline Rubia peregrina & . & . & . & $10^{29.6}$ & . & . \\
\hline Juncus maritimus & & & $76^{80.7}$ & 7 & . & . \\
\hline Orchis laxiflora subsp. palustris & 25 & $25^{22.2}$ & . & 10 & . & . \\
\hline Cirsium creticum & . & $38^{46.6}$ & . & 10 & 3 & . \\
\hline Samolus valerandi & 25 & 12 & . & $48^{42.8}$ & 2 & . \\
\hline Apium nodiflorum & $50^{59.1}$ & . & 5 & . & 6 & . \\
\hline Dorycnium rectum & 25 & $75^{66.4}$ & . & 3 & 5 & . \\
\hline Calamagrostis epigejos & . & . & $14^{28.6}$ & . & 5 & . \\
\hline Calystegia sepium & . & . & $38^{32.7}$ & $31^{23.4}$ & 11 & . \\
\hline Carex flava & . & . & . & . & $11^{30.0}$ & . \\
\hline Sparganium erectum & . & . & . & . & $11^{30.0}$ & . \\
\hline Pulicaria dysenterica & & 25 & $29^{24.7}$ & 10 & 3 & . \\
\hline Cirsium alatum & . & . & $14^{34.9}$ & . & . & . \\
\hline Inula salicina subsp. aspera & . & . & $14^{34.9}$ & . & . & . \\
\hline Poacynum russanovii & . & . & $24^{45.5}$ & . & . & . \\
\hline Elytrigia elongata & . & . & $29^{50.0}$ & . & . & . \\
\hline Carex extensa & . & . & $19^{40.5}$ & . & . & . \\
\hline Inula crithmoides & . & . & $14^{34.9}$ & . & . & . \\
\hline Festuca arundinacea & . & 12 & . & . & 2 & . \\
\hline
\end{tabular}

\section{References}

Allorge, M. P. 1921: Plant associations of French Vexin. Revue générale de Botanique 33: 626-629 [in French].

Andrienko-Malyuk, T. L. \& Dubyna, D. V. 2009: Cladieta marisci In: Didukh, Ya. P. (eds.): Green Data Book of Ukraine. Al'terpres, Kyiv, pp. 272-273 [in Ukrainian].

Andrienko, T. L., Kagalo, O. O., Kuzyarin, O. T. Danylyk, I. M., Umanets, O. Y. 2009: Cladium mariscus (L.) Pohl s.l. In: Didukh, Ya. P. (eds.): Red Data Book of Ukraine. Plants. Globalkonsaltyng, Kyiv, pp. 104 [in Ukrainian].

Ardamatskaya, T. B., Bilinskaya, O. S., Boyko, M. F., Geluta, V. P., Davydok, V. P., Dubyna, D. V., Zykov, A. E., Kondratenko, N. G., Kotenko, A. G., Kotenko, T. I., Movchan, Ju. V., Moysienko, I. I., Monchenko, V. I., Seljunina, Z. V., Starenkij, O. F., Tihonenko, Ju. Ja., Khodosovtsev A. E., Chernjakov, D. A., Shejgas, I. Ja., \& Shelyag-Sosonko, J. R. 2000: Biodiversity of the Jarylgach: Modern State and Ways for Conservation. Vestnik zoologii, Kiev, 234 pp. [in Russian].

Barbarych, A. I. 1962: Sword of grass in Ukraine - a witness of long past epochs of the development of its vegetation. Yearbook of the Ukrainian Botanical Society 3: 52-53 [in Ukrainian].
Biondi, E., Blasi, C., Allegrezza, M., Anzellotti, I., Azzella, M. M., Carli, E., Casavecchia, S., Copiz, R., Del Vico, E., Facioni, L., Galdenzi, D., Gasparri, R., Lasen, C., Pesaresi, S., Poldini, L., Sburlino, G., Taffetani, F., Vagge, I., Zitti, S. \& Zivkovic, L. 2014: Plant communities of Italy: The Vegetation Prodrome. Plant Biosystems 148(4): 728-814. doi:10.1080/11263504.2014.948527.

Biondi, E., Casavecchia, S. \& Guerra, V. 2006: Analysis of vegetation diversity in relation to the geomorphological characteristics in the Salento coasts (Apulia-Italy). Fitosociologia 43(1): 25-38.

Bohn, U. \& Neuhäusl, R. 2000: Map of the Natural Vegetation of Europe. Part 2. Legend (Folded Maps). BfN-Schriftenvertrieb, 156 pp.

Borsukevych, L. M. 2008: Distribution and ecological-coenotic peculiarities of Cladium mariscus (L.) Pohl. in Lviv region. Ukrainian Botanical Journal 65(1): 58-65 [in Ukrainian].

Borysova, O. V. \& Chorna, G. A. 2011: Contributions to the flora and syntaxonomy of Ukrainian Charophytes. Ukrainian Botanical Journal 68(1): 105-112 [in Ukrainian].

Braun-Blanquet, J. \& de Bolos, O. 1957: The plant communities of the Middle Ebro Basin and their dynamism. Anales de la Estación experimental de Aula Dei 5(1-4): 1-274 [in French]. 
Braun-Blanquet, J. 1964: Pflanzensoziologie. Grundzüge der Vegetationskunde. 3. Aufl. Springer-Verlag, Wien-New York, 865 pp.

Buczek, A. 2005: Habitat conditions, ecology, resources and protection of the Saw sedge Cladium mariscus (L.) Pohl. in the Lublin macroregion. Acta Agrophysica 129: 127 pp. [in Polish].

Castroviejo, S. 2007: Cladium. In: Castroviejo S. et al. (eds.): Flora iberica: plantas vasculares de la Península Ibérica e Islas Baleares. XVIII. Real Jardín Botánico, Madrid, pp. 102-104 [in Spanish].

Chorna, G. A. 2013: Vegetation of reservoirs and marshes of the foreststeppe of Ukraine. FOP Zhovtyy O.O., Uman, 304 pp. [in Ukrainian].

Cirujano, S. 1980: The La Mancha lagoons and their vegetation. Anales del Jardín Botánico de Madrid 37(1): 155-192. [in Spanish].

Conesa, J. A. 1991: Vegetal communities of the a reservoir DutxesaSecairodalies, I. Aquatic, halophilic, rocky, ruderal, nitro-halophilic and arvenses communities. de 1' Institut d' Estudis Ilerdencs CIÈNCIES 49: 1-287 [in Catalan].

Danylyk, I. M. 2011: Taxonomic diagnosis of Cyperaceae family Juss. in flora of Ukraine. Scientific Fundamentals of Preservation of Biotic Diversity 2(1): 51-86 [in Ukrainian].

Danylyk, I. M. 2012: System of Cyperaceae Juss. in flora of Ukraine. Ukrainian Botanical Journal 69(3): 337-351 [in Ukrainian].

Datsyuk, V. \& Andrienko, T. 2013: The largest in Ukraine locality of rare groups Schoenus ferrugineus L. and Cladium mariscus (L.) Pohl. (Cyperaceae) on the Volynsky Forest Plateau. Science Journal of Lesya Ukrainka Eastern European National University 14: 8-13 [in Ukrainian].

Dengler, J., Koska, I., Timmermann, T., Berg, C., Clausnitzer, U., Isermann, M., Linke, C., Päzolt, J., Polte, T. \& Spangenberg, A. 2004: New descriptions and typifications of syntaxa within the project "Plant communities of Mecklenburg-Vorpommern and their vulnerability" - Part II. Feddes Repertorium 115 (3-4): 343-392. doi:10.1002/ fedr.200411043.

Detailed final conclusions on the representation of habitats from Res. No. 4 (1996) of the Bern Convention in proposed Emerald sites in the Republic of Moldova, the Russian Federation and Ukraine (Steppic, Alpine-Caucasus and Black Sea). 2016: Emerald Biogeographical Seminar STE - ALP (Caucasus). 12 pp.

Didukh, Ya. P. 2011: The ecological scales for the species of Ukrainian flora and their use in synphytoindication. Phytosociocentre, Kyiv, 176 pp.

Dubyna, D. V., Neuhäuslová, Z., Dziuba, T. P. \& Shelyag-Sosonko, Yu. R. 2004: Classification and prodromus water vegetation, wetland areas and arenas of Northern Black Sea coast. Phytosociocenter, Kyiv, 200 pp. [in Ukrainian].

Dubyna, D. V., Dziuba, T. P., Neuhäuslová, Z., Solomakha, V. A., Tyshchenko, O. V. \& Shelyag-Sosonko, Yu. R. 2007: Halophytic vegetation. Classes Bolboschoenetea maritimi, Festuco-Puccinellietea, Molinio-Juncetea, Crypsietea aculeatae, Thero-Salicornietea strictae, Salicornietea fruticosae, Juncetea maritimi. Vegetation of Ukraine. Phytosociocenter, Kyiv, 315 pp. [in Ukrainian].

Dubyna, D. V., Dziuba, T. P. \& Iemelianova, S. M. 2014: Syntaxonomy of the Phragmito-Magnocaricetea class in Ukraine. Ukrainian Botanical Journal 71(3): 263-274. [in Ukrainian].

Dubyna, D. V., Dziuba T. P. (eds.) 2019: Prodromus of vegetation of Ukraine. Naukova dumka, Kyiv, 783 p. [in Ukrainian].
Dziuba, T. P. 2008: Syntaxonomic position and structure of the class Bolboschoenetea maritimi Vicherek et R. Tx. 1969 in the Northern Black Sea Region. Ukrainian Botanical Journal 65 (4): 485-494 [in Ukrainian].

Egorova, T. V. 1976: Sem. 178. Cyperaceae Juss. - Sedge. In: Fedorov, A. A. (eds.): Flora of the European part of the USSR (Vol. 2). Science, Leningrad, pp. 83-219 [in Russian].

Ellenberg, H., Weber, H. E., Düll, R., Wirth, V., Werner, W. \& Paulissen, D. 1991: Zeigerwerte von Pflanzen in Mitteleuropa. Scripta Geobotanica 18, 1-248.

$\mathrm{eVeg}$ - a database upon European vegetations. Published on the Internet https://www.e-veg.net/en/app/4202 [last accessed on 2018].

Gałka, M. \& Tobolski, K. 2012: Palaeoecological studies on the decline of Cladium mariscus (Cyperaceae) in NE Poland. Annales Botanici Fennici 49: 305-318. doi:10.5735/085.049.0602.

Gradstein, S. R. \& Smittenberg, J. H. 1977: The hydrophilous vegetation of western Crete. Vegetatio 34: 65-86.

Habitats Naturels supports de la biodiversité. Published on the Internet http://habitats-naturels.info/prodromephotos/ii-vegetation-amphibiedes-rivieres-sources-et-marais-3/ [last accessed on 2018].

Habitat Italia. 53.3 Fen-sedge beds (Cladietum marisci) Published on the Internet http://vnr.unipg.it/habitat/cerca.do?formato=stampa\&idS egnalazione $=146$ [last accessed on 2018].

Hájková, P., Jamrichová, E., Horsák, M. \& Hájek, M. 2013: Holocene history of a Cladium mariscus-dominated calcareous fen in Slovakia: vegetation stability and landscape development. Preslia 85: 289-315.

Illichevskyi, S. O. 1941: Relic islands and the northwestern coast of the Black Sea. Soviet Botany 4: 89-95 [in Russian].

Interpretation Manual of European Union Habitats - EUR28 (2013). Published on the Internet https://ec.europa.eu/environment/nature/ legislation/habitatsdirective/docs/Int_Manual_EU28.pdf [last accessed on 2019].

Kostina, N. V. 2013: Indexes of similarity and disimilarity for territory zoning based on local floras. News of the Samara Scientific Center of the Russian Academy of Sciences 15(3): 2160-2168 [in Russian].

Kuzyarin, O. \& Zhizhin, O. 2008: Phytosociological characteristics of peat "Pechenia" (Male Polissya). Proceedings of the Scientific Society of them. Shevchenko Ecological collection. Research of biotic and landscape diversity and its preservation 23: 276-284 [in Ukrainian].

Lájer, K. 2006: About the association of Schoenus nigricans L. in Hungary. Flora Pannonica 4: 81-97 [in Hungarian].

Landucci, F., Šumberová, K., Tichý, L., Hennekens, S., Aunina, L., Biță-Nicolae, C., Borsukevych, L., Bobrov A., Čarni, A., De Bie, E., Golub V., Hrivnák, R., Iemelianova, S., Jandt, U., Jansen, F., Kącki, Z., Lájer, K., Papastergiadou E., Šilc U., Sinkevičienè, Z., Stančić, Z., Stepanovič, J., Teteryuk, B., Tzonev R., Venanzoni, R., Zelnik, I., Chytrý, M. 2020: Classification of the European marsh vegetation (Phragmito-Magnocaricetea) to the association level. Applied Vegetation Science 23:1-20. doi: 10.1111/avsc.12484.

Lastrucci, L., Dell'Olmo, L., Foggi, B., Massi, L., Nuccio, C., Vicenti, C. \& Viciani, D. 2017: Contribution to the knowledge of the vegetation of the Lake Massaciuccoli (northern Tuscany, Italy). Plant Sociology 54(1): 67-87. doi:10.7338/pls2017541/03. 
Mavrodiev, E. V., Laktionov, A. P., \& Alekseev, J. E. 2015: About new dogbane of south-eastern European Russia due to the acceptance of the genus Poacynum Baill. (Apocynaceae)]. Novosti Sistematiki Vysshykh Rasteniy 46: 157-163 [in Russian].

Mooney, E. P. \& O'Connell, M. 1990: The phytosociology and ecology of the aquatic and wetland plant communities of the Lower Corrib Basin, County Galway. Proceedings of the Royal Irish Academy. Section B: Biological, Geological, and Chemical Science 90: 57-97.

Mosyakin, S. L., \& Fedoronchuk, M. M. 1999: Vascular Plants of Ukraine. A nomenclature Checklist. M.G. Kholodny Institute of Botany, Kiev, 345 pp.

Mucina, L., Bueltmann, H., Dierßen, K., Theurillat, J.-P., Raus, T., Čarni, A., Šumberová, K., Willner, W., Dengler, J., Gavilán, R., Chytrý, M., Hájek, M., Di Pietro, R., Iakushenko, D., Pallas, J., Daniëls, F., Bergmeier, E., Santos Guerra, A., Ermakov, N. \& Tichý, L. 2016: Vegetation of Europe: Hierarchical floristic classification system of vascular plant, bryophyte, lichen, and algal communities. Applied Vegetation Science 19 (Suppl. 1): 3-264.

Pedrotti, F. (eds.) 2018: Climate gradients and biodiversity in mountains of Italy. Geobotany Studies. Springer, Switzerland. 198 pp. doi: 10.1007/978-3-319-67967-9.

Peel, M. C., Finlayson, B. L. \& McMahon, T. A. 2007: Updated world map of the Köppen-Geiger climate classification. Hydrol. Earth Syst. Sci. Discuss., 4: 439-473. doi: 10.5194/hess-11-1633-2007.

Perrino, E. V., Tomaselli, V., Costa, R. \& Pavone, P. 2013: Conservation status of habitats (Directive 92/43 EEC) of coastal and low hill belts in a Mediterranean biodiversity hot spot (Gargano - Italy). Plant Biosystems - An International Journal Dealing with all Aspects of Plant Biology. Official Journal of the Societa Botanica Italiana 147(4): 1006-1028. doi: 10.1080/11263504.2013.860052.

Pirone, G. 2014: Notes on the vegetation diversity on the Adriatic and Ionian Italian coasts: the dunes and cliffs. Plant Sociology 51(1): 7-18. doi: $10.7338 / \mathrm{pls} 2014512 S 1 / 01$

Pirone, G., Ciaschetti, G., Di Martino, L., Cianfaglione, K., Giallonardo, T., \& Frattaroli, A. R. 2014: Contribution to the knowledge of the coastal vegetation of Abruzzo (central Adriatic). Plant Sociology 51(1): 57-64. doi: 10.7338/pls2014512S1/08.

Plants of the World online (POWO). Published on the Internet http:// powo.science.kew.org/taxon/329463-2 [last accessed on 2020]

Pokorný, P., Sádlo, J. \& Bernardová, A. 2010: Holocene history of Cladium mariscus (L.) Pohl in the Czech Republic. Implications for species population dynamics and palaeoecology. Acta Palaeobotanica 50(1): 65-76.

Pravotorov, I. A. 1967: The question of the transgressive course of the last millennium on the northern lagoon coast of the northwestern part of the Black Sea. Geology of the coast and the bottom of the Black and Azov seas within the Ukrainian SSR. Kiev. Univ., 1: 33-41. [in Russian].

Ryan, W. B. F., Pitman, W. C. III, Major, C. O., Shimkus, K., Moskalenko, V., Jones G. A., Dimitrov, P., Gorür, N., Sakinçe, M., Yücef, H. 1997: An abrupt drowning of the Black Sea shelf. Marine Geology 138 (1-2): 119-126. doi: 10.1016/S0025-3227(97)00007-8.
Rivas-Martínez, S., Costa, M., Castroviejo, S. \& Valdés, E. 1980: The vegetation of Doñana (Huelva, Spain). Lazaroa 2: 5-190 [in Spanish].

Rivas-Martínez, S., Fernández-González, F., Loidi, J., Lousã, M. \& Penas, A. 2001: Syntaxonomical checklist of vascular plant communities of Spain and Portugal to association level. Itinera Geobotanica 14: 5-341.

Roleček, J., Tichý, L., Zelený, D., Chytrý, M. 2009: Modified TWINSPAN classification in which the hierarchy respects clusterheterogeneity. Journal of Vegetation Science 20: 596-602.

Shaposhnikova, A. O. 2017: The current state and topical directions of vegetation research of National Nature Park "Dzharylgachsky". Chornomorski Botanical Journal 13(2): 239-251. doi:10.14255/23089628/17.132/10 [in Ukrainian].

Stančić, Z., Žganec, K. \& Gottstein, S. 2010: Marshland vegetation of Plitvice Lakes National Park (Croatia). Candollea 65(1): 147-167. doi $10.15553 / \mathrm{c} 2010 \mathrm{v} 651 \mathrm{a} 16$.

Taffetani, F. (eds.). 2011: Bosco Fantine. A retrodontal wetland of high naturalistic and environmental value in the Municipality of Campomarino (CB). I Quaderni della Selva, Marche, 133 pp. [in Italian].

Theocharopoulos, M., Georgiadis, T., Dimitrellos, G., Chochliouros, S. \& Tiniakou, A. 2006: Vegetation types with Cladium mariscus (Cyperaceae) in Greece. Willdenowia 36 (Special Issue): 247-256.

Tichý, L. 2002: JUICE, software for vegetataion classification. Journal of Vegetation Science 13: 451-453.

Tzvelev, N. N. 1966: About some species of Transcaucasia. Novosti Sistematiki Vysshykh Rasteniy 3: 292-296 [in Russian].

Verloove, F. 2012: Notes on some Cyperaceae from Gran Canaria (Canary Islands, Spain). Webbia 67(1): 93-99. doi: 10.1080/00837792.2012.10670910.

Verhoeven, J. T. A. (eds.) 1992: Fens and Bogs in the Netherlands: Vegetation, History, Nutrient Dynamics and Conservation. Geobotany 18. Springer-Science+Buisness Media, B.V. 491 pp.

Weber, H. E., Moravec, J. \& Theurillat, J.-P. 2000: International Code of Phytosociological Nomenclature. 3rd edition. Journal of Vegetation Science 11: 739-768.

Westoff, V. \& van der Maarel, E. 1973: The Braun-Blanquet approach. In Tüxen, R. (ed.): Handbook of vegetation science. Ordination and classification of communities. Part 5. Junk, Hague, pp. 617-726.

Wheeler, B. D. 1980: Plant communities of rich-fen systems in England and Wales. Journal of Ecology, 68: 365-395.

Yaschenko, P. T. \& Turich, V. V. 2007: Swamp-grass marsh (Cladium mariscus (L.) Pohl.) as a rare species of the flora of the Shatsk National Nature Park and the results of monitoring according to its locality. National Forestry University of Ukraine. Scientific bulletin 17(5): 30-37 [in Ukrainian].

Zscheile, K. \& Schubert, J. (eds.) 2010: Anleitung für die Kartierung von Biotoptypen und FFH-Lebensraumtypen in MecklenburgVorpommern. Stand März, Güstrow, 289 pp. [in German]. 